\title{
Perubahan Pemanfaatan Ruang Sebelum Dan Sesudah Penetapan Kawasan Perkotaan Sarbagita di Kecamatan Kuta Utara
}

\author{
*I Putu Windhu Sanjaya, Agam Marsoyo \\ Departement Teknik Arsitektur dan Perencanaan, Magister Perencanaan Wilayah dan Kota, Universitas Gadjah Mada \\ *windhusanjaya@ymail.com
}

\section{INFO ARTIKEL}

Riwayat Artikel:

Diterima: 5 -2- 2019

Disetujui: 6 - 3 -2019

\section{Kata Kunci:}

Pemanfaatan Ruang Wilayah Pinggiran Kota Kawasan Strategis Nasional

Geographic Information System

\begin{abstract}
Abstrak: Kecamatan Kuta Utara merupakan wilayah pinggiran Kota Denpasar yang saat ini mengalami perkembangan pesat terutama pada pemanfaatan ruangnya. Sejak tahun 2011, Kecamatan Kuta Utara ditetapkan sebagai bagian wilayah pengembangan kawasan perkotaan Sarbagita yang merupakan kawasan strategis nasional. Kajian ini terkait perubahan pemanfaatan ruang untuk menggambarkan perubahan pemanfaatan ruang yang terjadi sebelum dan sesudah penetapan kawasan perkotaan Sarbagita. Analisis yang dilakukan adalah overlay peta perubahan penggunaan lahan pada tahun 2003, 2011 dan 2017. Hasil penelitian ini menunjukkan adanya perubahan pemanfaatan ruang yang pesat sejak periode tahun 2011 sampai 2017 yang ditunjukkan dengan perubahan lahan tidak terbangun menjadi lahan terbangun.
\end{abstract}

\begin{abstract}
Kuta Utara district is a suburb of Denpasar City which is currently experiencing rapid development, especially in its use of space. Since 2011, North Kuta District has been designated as part of the development area of the Sarbagita urban area which is a national strategic area. This study is related to changes in spatial use to describe changes in spatial use that occurred before and after the determination of the Sarbagita urban area. The analysis carried out was overlaying a map of land use change in 2003, 2011 and 2017. The results of this study indicate a rapid change in spatial use from the period 2011 to 2017 indicated by changes in land not built into built-up land.
\end{abstract}

\section{A. LATARBELAKANG}

Ketersediaan ruang di dalam kota tetap dan terbatas, maka meningkatnya kebutuhan ruang untuk tempat tinggal dan kedudukan fungsi-fungsi selalu akan mengambil ruang di daerah pinggiran kota. Peningkatan kebutuhan akan ruang kekotaan di wilayah pinggiran mengakibatkan terjadinya perubahan pemanfaatan ruang. Akibatnya, wilayah pinggiran yang pada mulanya memiliki pemanfaatan ruang yang berorientasi pada kegiatan pertanian mengalami perubahan menjadi berorientasi kekotaan [1].

Menurut Yunus (2008) [2], wilayah pinggiran kota memiliki pemanfaatan ruang yang paling dinamis dibandingkan dengan bagian wilayah lain baik di dalam kota maupun di daerah perdesaan. Wilayah pinggiran Kota merupakan sasaran pendatang baik penduduk maupun fungsi-fungsi yang berasal dari wilayah kota maupun wilayah perdesaan untuk bertempat tinggal atau berkedudukan.

Kecamatan Kuta Utara merupakan wilayah pinggiran Kota Denpasar yang saat ini mengalami perkembangan pesat terutama pada pemanfaatan ruangnya. Selain itu, Kecamatan Kuta Utara juga memiliki posisi yang stategis karena berada di sekitar kawasan strategis ekonomi di Bali selatan. Kecamatan Kuta Utara memiliki batas dengan berbagai wilayah yang memiliki nilai strategis ekonomi seperti Kota Denpasar yang merupakan pusat pemerintahan dan perekonomian di Propinsi Bali, Kecamatan Kuta yang merupakan pusat pariwisata di Bali Selatan dengan Pantai Kuta sebagai obyek wisata pavorit, dan Kota Mangupura pada wilayah administrasi Kecamatan Mengwi yang merupakan pusat pemerintahan Kabupaten Badung. Kondisi ini membuat Kecamatan 
Kuta Utara yang berada pada posisi strategis bagi pengembangan wilayah kekotaan. Kecamatan Kuta Utara dalam beberapa tahun terakhir memiliki perkembangan pesat pada perubahan lahan pertanian menjadi lahan terbangun.

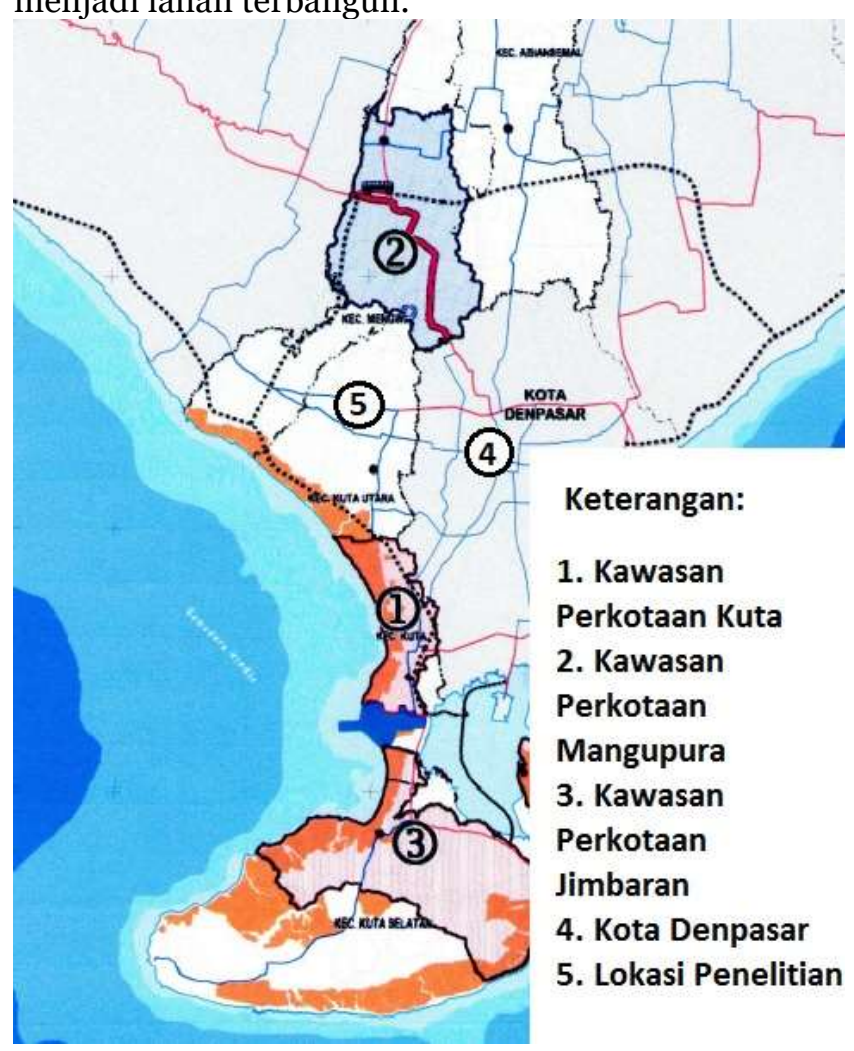

Gambar 1. Posisi Kecamatan Kuta Utara di antara Kawasan Strategis Ekonomi

Sumber: RTRW Badung 2013-2033

Sejak tahun 2011, Kecamatan Kuta Utara dimasukkan ke dalam pengembangan kawasan perkotaan Sarbagita. Kawasan perkotaan Sarbagita merupan kawasan strategis nasional yang diprioritaskan pengembangannya. Pada kawasan ini diatur tata ruang pengembangannya yang ditetapkan dalam perpres tahun 2011 tentang kawasan perkotaan Sarbagita. Pemanfaatan ruang yang ada di Kecamatan Kuta Utara ditetapkan pengembangannya dalam tata ruang wilayah perkotaan Sarbagita dengan Kota Denpasar dan Kecamatan Kuta sebagai perkotaan inti. Berdasarkan tata ruang wilayah perkotaan Sarbagita ini, wilayah Kecamatan Kuta Utara di peruntukan menjadi pemanfaatan ruang kekotaan. Sehingga dengan wilayah yang strategis dan peruntukkan lahan yang mendukung mengakibatkan para pengembang menjadi berminat dalam menanam investasi untuk pengembangan wilayah di Kecamatan Kuta Utara.

Tujuan dari penelitian ini adalah untuk menggambarkan perubahan pemanfaatan ruang sebelum dan sesudah penetapan kawasan perkotaan Sarbagita di Kecamatan Kuta Utara.

\section{B. METODE PENELITIAN}

Lokasi penelitian berada di Kecamatan Kuta Utara yang terletak pada $0^{\circ} 38^{\prime} 44.2$ " LS dan 115 oo9'42.3"BT dengan luas wilayah 33,86 $\mathrm{Km}^{2}$. Kecamatan Kuta Utara terdiri dari 3 desa dan 3 kelurahan yang meliputi Desa Dalung, Desa
Tibubeneng, Desa Canggu, Kelurahan Kerobokan Kaja, Kelurahan Kerobokan dan Kelurahan Kerobokan Kelod. Lokasi yang strategis dan kebijakan yang mendukung untuk pengembangan kawasan kekotaan mengakibatkan terjadinya perubahan pemanfaatan ruang yang pesat di Kecamatan Kuta Utara. Diperlukan kajian terkait perubahan pemanfaatan ruang untuk menggambarkan perubahan pemanfaatan ruang yang terjadi sebelum dan sesudah penetapakan kawasan perkotaan Sarbagita

Untuk mengetahui perubahan pemanfaatan ruang, dilakukan analisis terhadap kondisi fisik menggunakan analisis spasial dengan teknik overlay secara time series. Teknik analisis ini bertujuan untuk melihat perkembangan pemanfaatan ruang yang ditunjukkan dengan perkembangan penggunaan lahan pada tahun 2003 sampai dengan tahun 2017 yang dibagi dalam 2 periode (sebelum dan sesudah penetapan kawasan perkotaan Sarbagita). Sehingga hasil yang didapat dari analisis ini adalah luasan dan bentuk perubahan pemanfaatan ruang pada tiap periode.

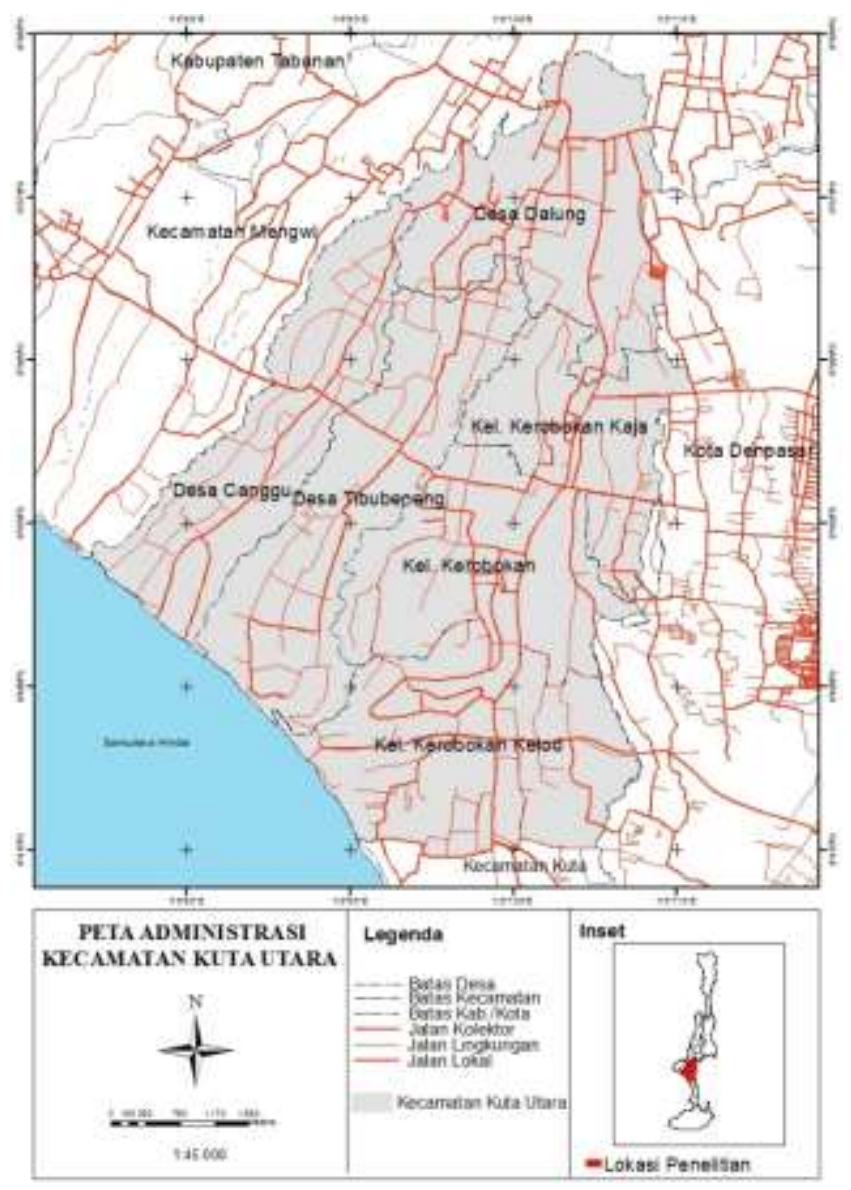

Gambar 2. Peta Administrasi Kecamatan Kuta Utara

\section{HASIL DAN PEMBAHASAN}

Kecamatan Kuta Utara pada mulanya memiliki pemanfaatan ruang yang beroreintasi pada kegiatan pertanian. Lahan pertanian yang ada di Kecamatan Kuta Utara adalah berupa lahan sawah dan lahan tegalan. Dominasi lahan sawah ini mencerminkan bahwa saat itu masyarakat di Kecamatan Kuta Utara yang memiliki 
profesi sebagai petani. Perkembangan yang terjadi di Kecamatan Kuta Utara mengakibatkan perubahan pemanfaatan ruang yang ditunjukkan dengan adanya perubahan bentuk penggunaan lahan tidak terbangun menjadi lahan terbangun yang menunjang kebutuhan akan ruang kekotaan. Selain terjadi perubahan pada bentuk lahan juga terjadi perubahan fungsi bangunan terutama pada bangunan rumah tinggal yang berfungsi ganda (tempat tinggal dan tempat usaha). Pembahasan perubahan pemanfaatan ruang di Kecamatan Kuta Utara dibahas dalam dua periode yaitu periode I ( Tahun 2003 sampai 2011) dan periode II (Tahun 2011 sampai 2017).

\section{Perubahan Pemanfaatan Ruang Pada Periode I (Tahun 2003 sampai 2011)}

Pada periode tahun 2003 sampai 2011, perubahan pemanfaatan ruang di Kecamatan Kuta Utara cenderung diakibatkan oleh adanya pengembang. Perubahan pada periode ini adalah lahan tidak terbangun berupa lahan pertanian yang berubah menjadi lahan terbangun berupa akomodasi pariwisata, perdagangan dan jasa serta perumahan. Adapun perubahan pemanfaatan ruang Kecamatan Kuta Utara pada periode tahun 2003 sampai 2011 dapat dilihat pada gambar berikut.

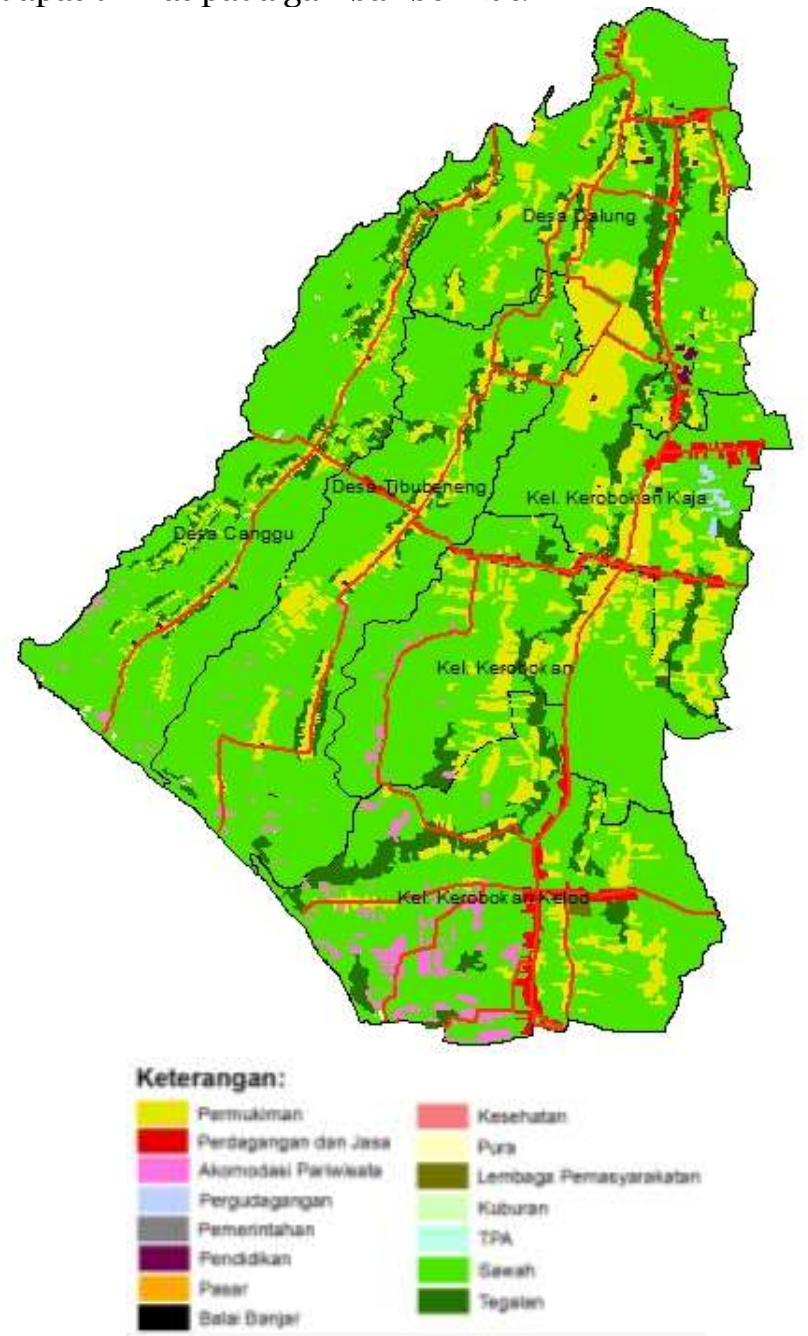

Gambar 3. Penggunaan Lahan Tahun 2003 Sumber: Hasil Analisis, 2018

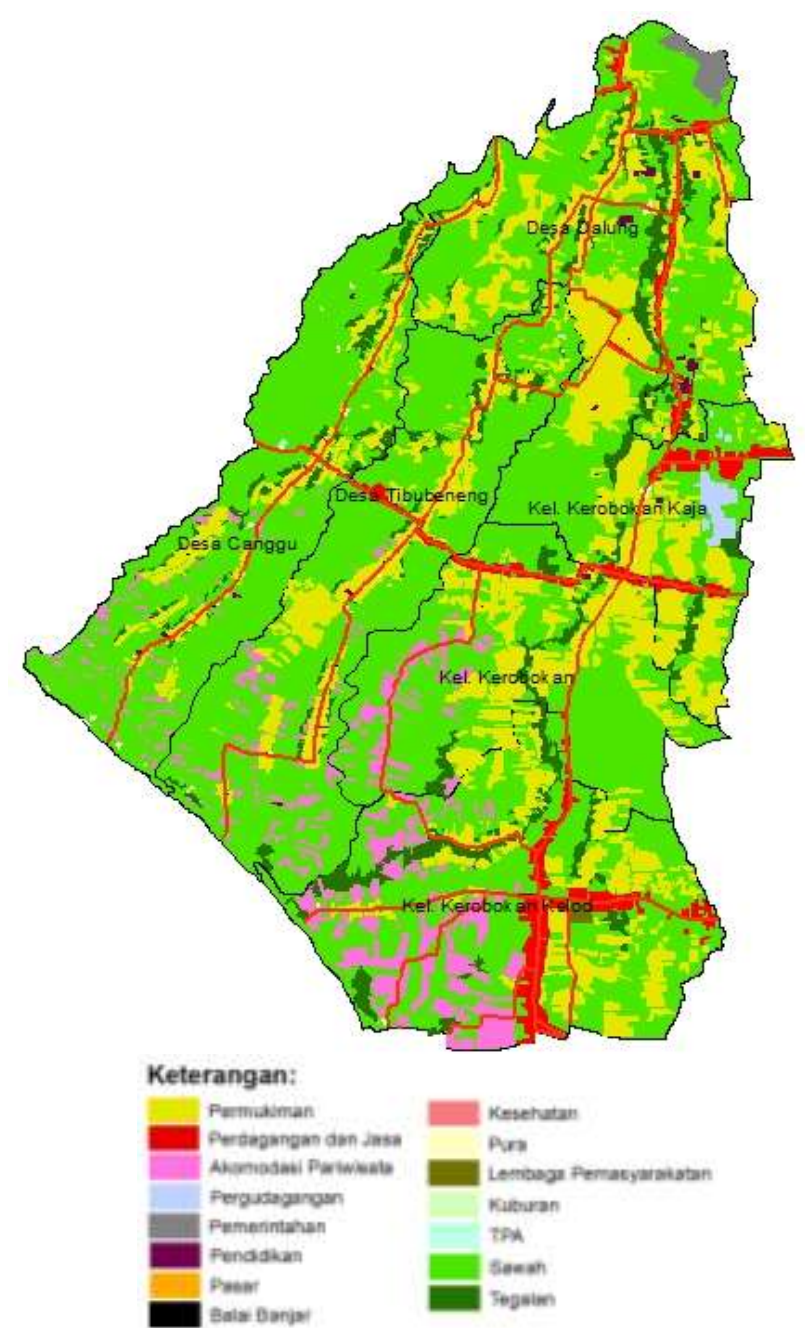

Gambar 4. Penggunaan Lahan Tahun 2011 Sumber: Hasil Analisis, 2018

Tabel 1. Penggunaan Lahan Tahun 2003 dan 2011

\begin{tabular}{llll}
\hline \multirow{2}{*}{$\begin{array}{l}\text { Penganan } \\
\text { Tegalan }\end{array}$} & \multicolumn{2}{c}{ Luas (ha) } & Keterangan \\
\cline { 2 - 3 } & $\mathbf{2 0 0 3}$ & $\mathbf{2 0 1 1}$ & \\
\hline Permukiman & 510,92 & 754,79 & $+243,87$ \\
\hline $\begin{array}{l}\text { Perdagangan } \\
\text { dan Jasa }\end{array}$ & 72,18 & 112,39 & $+40,21$ \\
\hline Pemerintah & 0,9 & 15,92 & $+15,02$ \\
\hline Fasilitas Sosial & $\mathbf{2 1 , 6 3}$ & $\mathbf{2 2 , 6 4}$ & $+1,01$ \\
\hline Sawah & 2459,61 & 2091,35 & $-368,26$ \\
\hline $\begin{array}{l}\text { Akomodasi } \\
\text { Pariwisata }\end{array}$ & 60,31 & 183,89 & $+123,58$ \\
\hline Pergudangan & 5,72 & 14,94 & $+9,22$ \\
\hline
\end{tabular}

Sumber: hasil analisis, 2018

Pada periode tahun 2003 sampai 2011, Kecamatan Kuta Utara mengalami perkembangan lahan terbangun berupa lahan perumahan, perdagangan dan jasa serta akomodasi pariwisata. Namun, pada periode tahun 2003 sampai tahun 2011, pemanfaatan ruang masih ditunjukkan dengan dominsasi lahan tidak terbangun berupa lahan sawah. 


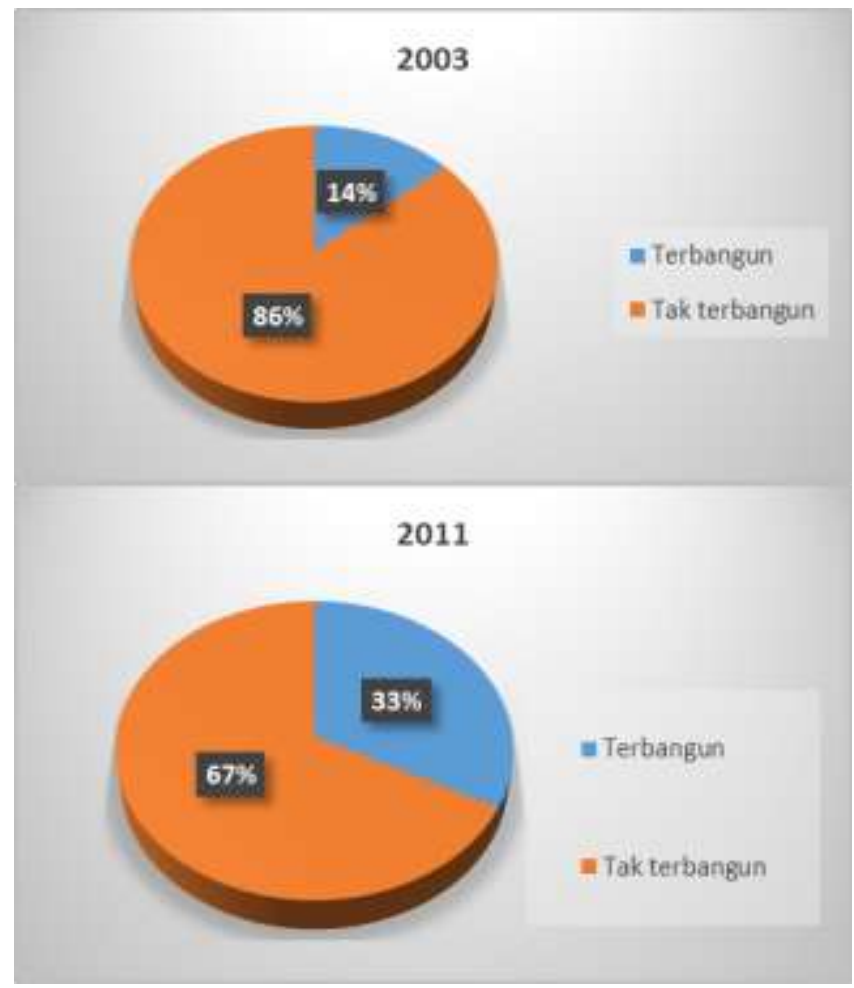

Gambar 5.Perbandingan luas lahan terbangun dan tak terbangun Kec.Kuta Utara tahun 2003-2011 Sumber: Hasil Analisis, 2018

Perubahan pemanfaatan ruang pada periode ini ditunjukkan dengan terjadinya perubahan lahan sawah menjadi perumahan. Pengembang memilih Kecamatan Kuta Utara sebagai lokasi pembangunan kawasan perumahan dikarenakan lokasinya yang berbatasan langsung dengan Kota Denpasar. Lokasi perkembangan perumahan seperti di Desa Dalung, Kelurahan Kerobokan Kaja dan Kelurahan Kerobokan Kelod yang memiliki batas langsung dengan Kota Denpasar dan akses penguhung yang baik.

Perubahan lain yang terjadi adalah perubahan lahan sawah menjadi perdagangan dan jasa. Keberadaan perguruna tinggi yang dipusatkan di Desa Dalung membawa dampak spasial bagi lingkungan sekitarnya. Banyaknya mahasiswa pendatang dari berbagai daerah menyebabkan penduduk di sekitar kampus memanfaatakan peluang tersebut dengan membangun fasilitas kebutuhan mahasiswa. Selain itu, jalan utama yang dibangun untuk menghubungkan Kota Denpasar dengan wilayah sekitarnya terutama di Kecamatan Kuta Utara seperti di Jalan Gatot Subroto Barat dan Jalan Tangkuban Perahu menyebabkan terjadinya perubahan pemanfaatan ruang berupa lahan sawah yang berubah menjadi lahan perdagangan dan jasa.

Kecamatan Kuta Utara mengalami perubahan pemanfaatan ruang berupa lahan sawah yang berubah menjadi lahan akomodasi pariwisata. Akomodasi pariwisata yang terdapat di wilayah pesisir Kecamatan Kuta Utara adalah berupa hotel, villa dan restoran yang dibangun oleh investor. Jarak yang dekat dengan obyek wisata Pantai Kuta yang telah berkembang sebeleumnya mengakibatkan pada wilayah pesisir kecamatan Kuta Utara ikut mengalami perkembangan untuk menunjang akomodasi dari adanya aktivitas pariwisata.

Perubahan lainnya, lahan sawah yang berada di Subak Kedampang di Kelurahan Kerobokan Kelod dan Subak Muding di Kelurahan Kerobokan Kaja melalui kebijakan penataan lahan pertanian mengamali kosnsolidasi lahan. Konsolidasi lahan ini dilakukan berdasarkan keputusan pemerintah dareah yang menentukan lahan sawah di subak tersebut menjadi lahan perkotaan. Lahan sawah yang mengalami konsolidasi ini kemudian mengalami perubahan menjadi lahan terbangun berupa pergudangan, perumahan serta perdagangan dan jasa. Selain itu, Berdasarkan RDTR Kecamatan Kuta Utara tahun 2003 yang mengalokasikan lahan yang berada di Desa Dalung untuk menjadi kawasan pusat pemerintah Kabupaten Badung mengakibatkan terjadi perubahan lahan sawah menjadi kawasan pemerintahan. Keterbatasan lahan di dalam wilayah administrasi Kota Mangupura dan ketersediaan lahan yang belum terbangun di Desa Dalung mendorong pemerintah untuk membebaskan lahan sawah masyarakat untuk dijadikan pusat pemerintahan.

Pada tahun 2011 terjadi perubahan pemanfaatan lahan sawah menjadi perdagangan dan jasa. Pertumbuhan pendudukan yang pesat akibat pesatnya pertumbuhan perumahan mengakibatkan kebutuhan ruang yang ada di Kecamatan Kuta Utara. Terjadi pertumbuhan bangunan perdagangan dan jasa yang mengorbankan lahan sawah produktif. Perubahan perdagangan dan jasa ini yaitu berupa bangunan pertokoaan dan bangunan ruko.

\section{Perubahan Pemanfaatan Ruang pada Periode II (Tahun 2011 sampai 2017)}

Pada periode tahun 2011 sampai 2017, perubahan pemanfaatan ruang yang terjadi ditunjukkan dengan semakin pesatnya perkembangan perumahan, akomodasi pariwisata serta perdagangan dan jasa yang ada di Kecamatan Kuta Utara. Perkembangan pemanfaatan ruang pada periode ini tidak hanya merubah pemanfaatan ruang pada lahan hijau seperti sawah dan tegalan, namun juga merubah pemanfaatan ruang pada bangunan rumah tinggal.

Pada periode ini perubahan lahan sawah dan tegalan menjadi kawasan terbangun semakin pesat dikarenakan adanya kebijakan yang mendukung sehingga mendorong para investor semakin berminat dalam membangun berbagai usaha di Kecamatan Kuta Utara. Disisi lain masyarakat lokal juga tidak kalah dalam membuka peluang usaha yang bisa dikembangkan baik merubah lahan pertanian maupun merubah bagian rumah tinggalnya. Adapun perbandingan penggunaan lahan pada periode ini dapat dilihat pada gambar 5 dan gambar 6 . 


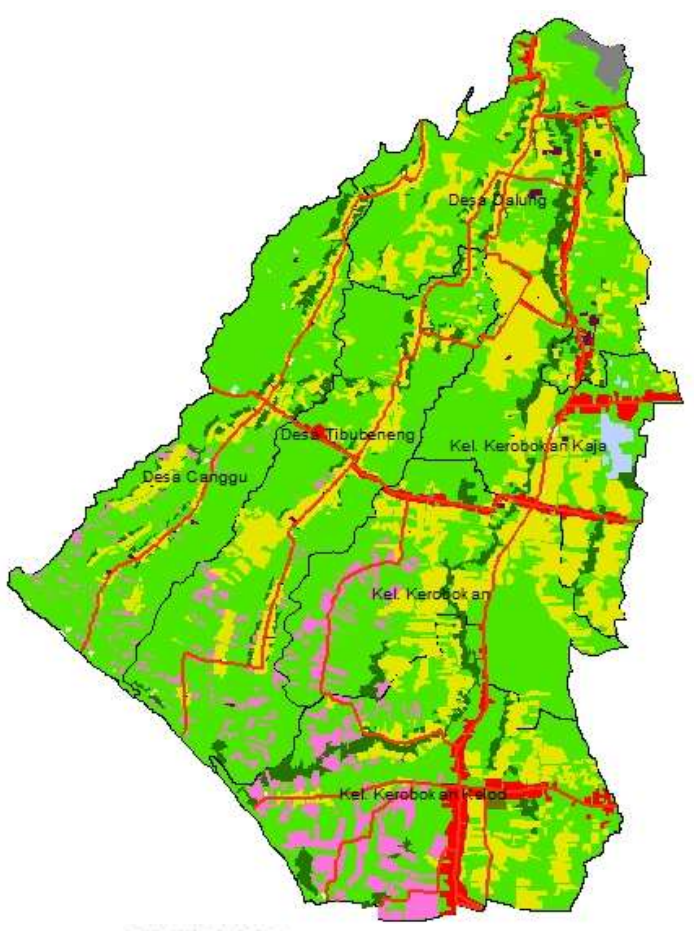

Keterangan:

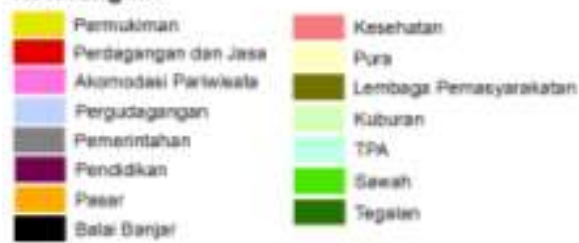

Gambar 6. Penggunaan Lahan Tahun 2011 Sumber: Hasil Analisis, 2018
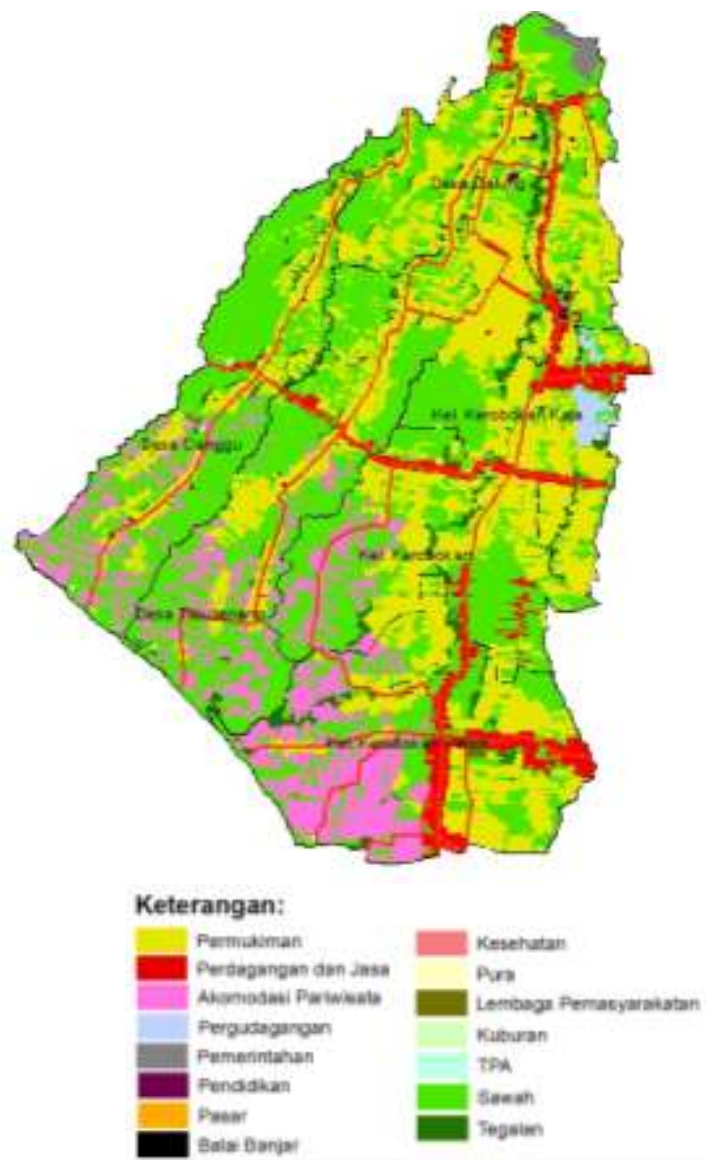

Gambar 7. Penggunaan Lahan Tahun 2017 Sumber: Hasil Analisis, 2018
Tabel 2. Penggunaan Lahan Tahun 2011 dan 2017

\begin{tabular}{llll}
\hline \multirow{2}{*}{$\begin{array}{l}\text { Penggunaan } \\
\text { Lahan }\end{array}$} & \multicolumn{2}{c}{ Luas (ha) } & \multirow{2}{*}{ Keterangan } \\
\cline { 2 - 3 } & $\mathbf{2 0 1 1}$ & $\mathbf{2 0 1 7}$ & \\
\hline Tegalan & 190,08 & 107,42 & $-82,66$ \\
\hline Permukiman & 754,79 & 1124,29 & $+369,5$ \\
\hline $\begin{array}{l}\text { Perdagangan } \\
\text { dan Jasa }\end{array}$ & 112,39 & 181,72 & $+69,33$ \\
\hline Pemerintahan & 15,92 & 15,92 & $\mathrm{O}$ \\
\hline Fasilitas Sosial & 22,64 & 22,64 & $\mathrm{O}$ \\
\hline Sawah & 2091,35 & 1504,06 & $-587,29$ \\
\hline $\begin{array}{l}\text { Akomodasi } \\
\text { Pariwisata }\end{array}$ & 183,89 & 407,55 & $+223,66$ \\
\hline Pergudangan & 14,94 & 22,4 & $+7,46$ \\
\hline Sumber
\end{tabular}

Sumber : hasil analisis, 2018

Pada periode tahun 2011 sampai 2017 lahan terbangun mengalami perubahan yang lebih pesat dibandingkan dengan periode 1 . Pada periode ini perkembangan lahan yang mendominasi adalah berupa perumahan, lahan akomodasi pariwisata, serta lahan perdagangan dan jasa. Pada periode ini lahan terbangun lebih mendominasi lahan tidak terbangun.

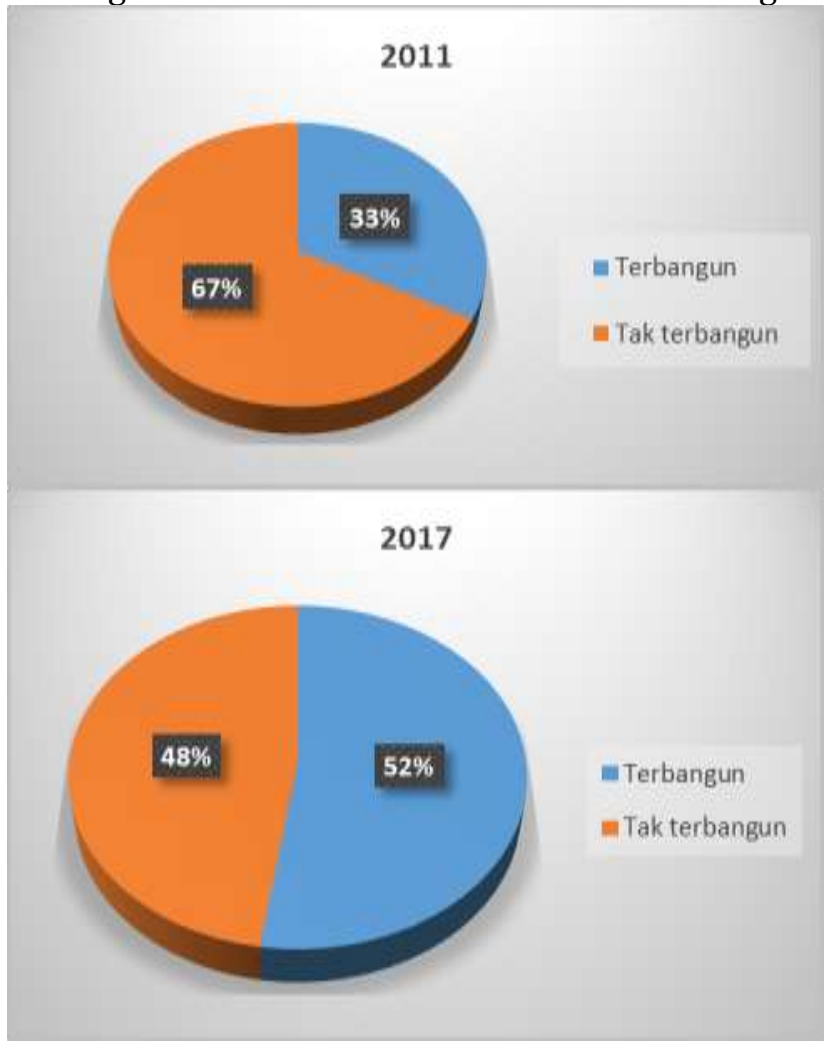

Gambar8. Perbandingan luas lahan terbangun dan tak terbangun Kec.Kuta Utara tahun 2011-2017 Sumber: Hasil Analisis, 2018

Pada periode tahun 2011 sampai tahun 2017, terjadi perubahan pemanfaatan ruang berupa lahan tidak terbangun berupa lahan sawah dan tegalan yang berubah menjadi lahan terbangun berupa lahan perumahan, lahan perdagangan dan jasa serta lahan akomodasi pariwisata. 
Kecamatan Kuta Utara yang ditetapkan menjadi pengembangan kawasan perkotaan Sarbagita mengakibatkan peruntukkan lahan yang ada di Kecamatan Kuta Utara lebih mengarah pada lahan kekotaan. Kebijakan ini mengakibatkan harga lahan yang meningkat pesat. Sejak saat itu banyak masyarakat yang menjual maupun mengontrakkan lahan mereka karena dirasa lebih menguntungkan dari pada dimanfaatakan untuk kegiatan pertanian. Lahan yang mengalami perubahan hak milik inilah yang mengalami perubahan menjadi lahan terbangun. Lahan terbangun yang berkembang adalah lahan akomodasi pariwisata, perumahan serta perdagangan dan jasa. Lahan yang ada di Kecamatan Kuta Utara bernilai tinggai bagi investor dikarenakan lokasinya yang strategis yaitu berada diantara pusat kegiatan perkotaan yaitu Kota Denpasar, Kota Mangupura dan Kecamatan Kuta yang menjadi simpul-simpul kegiatan di Bali selatan.

Selain itu, masayarkat lokal yang melihat peluang dengan berkembang pesatnya obyek pariwisata yang ada di Kecamatan Kuta Utara membangun akomodasi pariwisata berupa guest house yang dilengkapi oleh berbagai fasilitas seperti kolam renang, free wifi, air panas, ac dan fasilitas lain yang menunjang. Kebutuhan akan akomodasi yang disebabkan oleh semakin meningkatnya kunjungan wisatan asing mengakibatkan semakin berkembang pesatnya akomodasi guest house di wilayah pesisir Kecamatan Kuta Utara seperti di Keluarahan Kerobokan Kelod, Desa Canggu dan Desa Tibubeneng.

Perubahan lain yang terjadi pada periode ini adalah terjadi perubahan rumah tinggal masyarakat lokal menjadi fungsi ganda yaitu sebagai tempat tinggal dan tempat usaha. Kecamatan Kuta Utara yang telah berkembang pesat oleh adanya pertumbuhan penduduk dan kawasan perumahan dan akomodasi pariwisata dimanfaatkan oleh masyarakat lokal dengan cara mengembangkan rumah tinggalnya menjadi tempat usaha. Masyarakat lokal mengembangkan bangunan maupun lahan pekarangan menjadi berbagai tempat usaha baik untuk berjualan sendiri maupun disewakan.

Rumah tinggal yang dirubah masyarakat menjadi tempat usaha berlokasi pada ruas jalan utama karena bernilai ekonomi tinggi. Di desa dalung, ruas jalan yang terdapat rumah tinggal yang berubah menjadi tempat usaha yaitu pada Jalan Raya Dalung, Jalan Raya Padang Luwih dan jalan lainnya yang memiliki tingkat lalu lintas yang tinggi. Masyarakat lokal Desa dalung yang merubah rumah tinggalnya menjadi tempat usaha memiliki tujuan untuk menambah pendapatan. Tempat usaha baik yang disewakan maupun diusahakan sendiri dapat memberi pemasukan tambahan dengna memberdayakan anggota keluraga yang tidak memiliki pekerjaan, sedangkan pada tempat usaha yang disewakan oleh penduduk luar dapat memberi penghasilan tambahan bagi pemilik pada setiap bulannya.

Pertumbuhan penduduk yang meningkat pesat akibat berkembangnya kawasan perumahan di Desa Dalung mengakibatkan penduduk setempat memiliki inisiatif untuk mengembangkan lahan tempat tinggalnya menjadi peruntukkan perdagangan dan jasa. Akibatnya terjadi multi use pada lahan tempat tinggal yaitu selain sebagai tempat tinggal juga sebagai peruntukan perdagangan dan jasa. Masyarakat lokal merubah rumah tinggal mereka menjadi tempat usaha dengan beberapa cara. Pada rumah tinggal yang masih memiliki lahan pekarangan yang cukup, masyarkat cenderung merubah lahan pekarangan yang berada dekat dengan jalan raya menjadi tempat usaha, sedangkan pada rumah tinggal yang sudah tidak memiliki lahan pekarangan yang kosong, masyarakat memodifikasi bangunan rumah yang telah ada untuk dapat dirubah menjadi tempat usaha. Proses modifikasi ini yaitu dengan membagi peruntukan bangunan yang telah ada sebelumnya. Bagian bangunan yang berfungsi sebagai tempat tinggal diposisikan lebih ke arah dalam rumah maupun ditempatkan pada lantai atas, kemudian bagian bangunan yang berfungsi menjadi tempat usaha berada di pinggir jalan.

Usaha yang berkembang dengan adanya fungsi ganda pada rumah tinggal di Desa Dalung memiliki berbagai macam usaha, adapaun diantaranya yaitu warung kelontong, jasa laundry, warung makan, jasa fotocopy dan sebagainya.

Sedangkan pada rumah tinggal yang memiliki kedekatan dengan obyek wisata seperti di Desa Canggu, Desa Tibubeneng dan Kelurahan Kerobokan Kelod cenderung mengalami perubahan menajadi peruntukan akmodasi pariwisata seperti restoran dan toko aksesoris untuk wisatawan. Selain itu, juga berkembang sebagai tempat menginap wisatawan berupa home stay. 


\section{SIMPULAN DAN SARAN}

Pada periode 1 (sebelum ditetapkan sebagai kawasan perkotaan sarbagita), Kecamatan Kuta Utara mengalami perubahan pemanfaatan ruang yang ditunjukkan dengan perubahan lahan tak terbangun menjadi lahan terbangun. Pada periode ini pemanfaatan ruang masih didominasi lahan pertanian. Perubahan pemanfaatan ruang yang terjadi adalah berupa lahan sawah dan tegalan yang berubah menjadi perumahan, perdagangan dan jasa, akomodasi pariwisata, Pergudangan dan pusat pemerintahan.

Pada periode 2 (setelah ditetapkan sebagai kawasan perkotaan sarbagita), Kecamatan Kuta Utara mengalami perubahan pemanfaatan ruang yang lebih tinggi dibandingkan pada periode 1 . Pada periode ini, perubahan pemanfaatan ruang tidak hanya ditunjukkan oleh perubahan lahan tidakk terbangun menjadi perubahan lahan terbangun, tetapi juga ditunjukkan oleh perubahan fungsi bangunan yaitu bangunan rumah tinggal yang berubah menjadi fungsi ganda (tempat tinggal dan tempat usaha).

\section{DAFTAR RUJUKAN}

[1]. Jayadinata, J, Tata Guna Tanah dalam perencanaan Perdesaan dan Perkotaan, Alumni, Bandung, 1986

[2]. Yunus, H.S, Dinamika Wilayah Peri-Urban Determinan Masa Depan Kota, Pustaka Pelajar, Yogyakarta, 2008

[3]. Sadyohutomo, Mulyono, Manajemen Kota dan Wilayah Realita dan Tantangan, Bumi Aksara, 2008

[4]. Suhardjo, A.J. Geografi Perdesaan Sebuah Antologi, Ideas Media, Yogyakarta, 2008

[5]. Yunus, H.S, Manajemen Kota Dari Perspektif Spasial, Pustaka Pelajar, Yogyakarta, 2015

[6]. Yunus, HS, Metodelogi Penelitian Wilayah Kontemporer, Pustka Pelajar, Yogyakarta, 2010 